\title{
THE IMPORTANCE OF FORENSIC ACCOUNTING IN FORENSIC ECONOMIC AND FINANCIAL EXAMINATION ${ }^{1}$
}

Review paper

\begin{tabular}{|l|l|l|}
\hline DOI 10.5937/zurbezkrim1902041C & COBISS.RS-ID 8631576 & UDK 343.983:657.632 \\
\hline
\end{tabular}

\author{
Aleksandar Čudan ${ }^{2}$ \\ University of Criminal Investigation and Police Studies, Belgrade \\ Dragan Cvetković \\ Belgrade Police Department, Criminal Police Administration
}

\begin{abstract}
Economics and financial expert witnesses too participate in the process of determining facts pertinant to a case. The need for a forensic examination in legal proceedings arises when the court does not have the knowledge necessary to determine all relevant facts and render a final judgment, which is the reason why courts engage expert witnesses to determine facts by applying knowledge and skills within their expertise. The topic of this paper is forensic accounting with a special emphasis on its importance and role in forensic financial examination. The aim of the paper is to emphasize the importance of forensic accounting in the purpose of forensic economic and financial examination and the need for its further improvement and development. The practical aim of this paper is to promote financial forensics as a profession of the new millennium. Given the turbulent past and expected future, the Republic of Serbia undoubtedly needs this type of personnel.
\end{abstract}

Keywords: forensic accounting, expert witness, ligal proceedings, fraud, forensic science

\section{INTRODUCTION}

Forensic science is an application of knowledge and technology from a wide range of scientific disciplines and it provides answers relevant to the court, be it in criminal or civil cases, meaning at the same time the application of science to administering the justice. In developed countries, that is, in the European Union, the number of forensic investigations has increased several times in the past decade, with the Netherlands Forensic Institute as one of the most developed institutes in Europe, in which the number of employees has tripled since the beginning of the new millennium, (Tjark, 2013: 3).

\footnotetext{
This paper is part the project entitled "Crime in Serbia and the Instruments of Government Response", which was funded and implemented by the Academy of Criminalistics and Police Studies in Belgrade - the 2015-2019 scientific research cycle.

2 Corresponding author: dr Aleksandar Čudan, Associate Professor, University of Criminal Investigation and Police Studies, Belgrade, Serbia. E-mail: aleksandar.cudan@kpu.edu.rs
} 
Forensic science has evolved in different directions, thus in the direction of forensic accounting as well, as a result of serious damage to the economy caused by fraud and fraudulent financial statements (Čudan, 2014). Forensic accounting is a special branch of accounting, which deals with the use of accounting expertise in the prevention and investigation of different types of criminal activities within a company as well as in gathering evidence relevant to a litgation. Numerous examples of financial scandals in the past period have highlighted the shortcomings and limitations of auditing in detecting criminal activities, including the need to apply forensic accounting knowledge and skills to investigating and detecting various criminal activities.

Forensic evidence is collected in a way to be admissible in a court of law. Forensic accounting does not function as an advocate for one side or the other. This is the reason why forensic experts and their knowledge become a link which complements and makes the combat against economic crime even more effective.

In modern conditions, it is almost impossible to conclude criminal proceedings in case of economic crimes, in which a forensic expert, as a source of evidence or person with relevant expertise and skills necessary to determine or evaluate an important fact, was not called upon to provide expert opinion. Adherence to professional rules and the enforcement of their actual application is possible through the use of innovative bookkeeping and accounting branches: forensic accounting. Given that forensic accountants, who are familiar not only with auditing, accounting and financial reporting but also with legal regulations and laws, actuarials, statistics, software tools, and personality psychology, are gaining an imortant role not only in fraud detection but also in the provision of economic and financial expert opinion in criminal or civil cases, with the aim of gathering evidence that is relevat to litigation and dipute resolution. Taking into account the above issues, it may be said that forensic economic and financial examination holds a special place among a wide array of forensic scientific disciplines.

This paper addresses the concept of forensic accounting, the scope and tasks of forensic accounting, the legal and institutional framework of forensic accounting and financial expertise, including the importance and role of economic and financial expert testimony in court proceedings.

\section{FORENSIC ACCOUNTING: CONCEPT, SCOPE, AND TASKS}

In modern usage, the terms forensics and forensic science are often interchangeable. Given that the adjective forensic is synonymous with legal or court-related, this substitution cannot be considered very precise. However, the term has become so well-established in modern usage that many dictionaries offer similar meanings of the terms forensics and forensic science.

In the broadest sense, forensic science means the application of knowledge and technology from various scientific disciplines to solving legal issues. In practical application, forensic science uses its own experiential methods and borrows methods from other scientific disciplines, adapting them to its own needs in practice, whereby the adapted and innovated ones necessarily gain practical instructive importance. Due to the use of various forensic analyses, 
this type of evidence often plays a final role in determining the guilt or innocence of the accused or defendant. In other words, forensic science involves the application of scientific methods to detecting and interpreting material traces, which is why the experts performing these tasks are called forensic scientists (Ivanovic and Ivanovic, 2013).

Although there are many definitions in the forensic accounting literature, the widely accepted and most complete definition is the one formally acknowledged by the Association of Certified Fraud Examiners (ACFE) ${ }^{3}$ according to which forensic accounting is defined as the use of accounting skills in potential or actual civil or criminal cases, including the generally accepted accounting and audit principles, to determine lost profits, income, asset values or to assess damage, includng the assessment of the efficasy of internal controls, uncovering a fraud or the performance of other activities requiring the inclusion of accounting expertise in the legal system (Cvetkovic and Djuric, 2017).

In addition to a wide range of applicatins, forensic accounting may be applied in two primary areas:

1. Investigative accounting is primarily aimed at detecting and uncovering fraud when it is suspected that a destructive unlowful act has been committed in the financial statements, that is, when the client's business is preventively audited. Investigative accounting involves a comprehensive investigation of criminal activitivities. It also integrates knowledge in accounting, auditing and investigative techniques and can take two forms:

a) Financial crime investigation - is a special discipline within forensic accounting that investigates financial statement fraud. This type of investigation involves taking a proactive and reactive approach to the methodology aimed at identifying financial statement fraud. This type of forensic accounting work is performed by investigators who typically work in the office of state controllers and investigative/ detective agencies, auditing agencies, and criminal police services. It is a team of experts with different knowledge, skills, and experience which they use to detect and document criminal activities.

b) Forensic auditing of financial statements is a new specialized service used in the financial statement audit process. Forensic audit means engaging the services of an auditor with specialist training and experience in fraud prevention and detection through an auditing agency. ${ }^{4}$

2) Litigation support - the provision of professional services when certain acts have already been identified and brought before the court. It refers to the provision of professional services to persons involved in a legal dispute. Profes-

\footnotetext{
3 Association of Certified Fraud Examiners (ACFE) is an independent professional multidisciplinary organization covering a large number of forensic disciplines or similar fields, including forensic accounting. The purpose of the ACFE is to provide its members with continuous training in the area of forensic accounting and counseling. The ACFE has raised standards to a higher standard through education and training. One of the certifications issued by ACFE is Certified Forensic Accountant (Cr.FA). the ACFE is also a leader in anti-fraud training, gaining a high reputation and public confidence in the profession as an instrument for combating fraud. The primary aim of this organization is to minimaze fraud occurences and assist its members in fraud detection.

4 Forensic Audit vs. Financial Statement Audits, Currents Accounts, (2008). Retrived from: http:// www.iagforensics.com/wp-content/uploads/2009/12/GSCPA-Thomas Buckhoff-ct08.pdf
} 
sional services are provided by persons with accounting and auditing skills and other knowledge contributing to the resolution of a dispute, such as economic and financial expertise, consulting and other services (Aleksić, et al., 2015). The American Institute of Certified Public Accountants (AICPA) defines litigation services as any professional assistance given to lawyers by non-lawyers in litigation process. Litigation services can be classified into three areas:

a) Consulting expert-forensic accountants provide advice on accounting and financial matters relevant to a ligal dispute. Consultants do not testify as expert witnesses in trials. Rather, they assist the lawyers and/or the parties to the litigation in various ways, using their accounting and auditing knowledge and skills. A forensic accountant can measure the economic damages or losses resulting from, for example, a breach or termination of a contract, then manage, sort, index and summarize a large number of accounting information to make it understandable and usable in a court of law.

b) Forensic economic and financial examination services- based on their experience, knowledge and expertise, forensic accountants may serve as expert witnesses. As expert witnesses, forensic accountants may provide the opinion in the form of a report on the subject matter in accordance with the instructions they are given. In the proceedings already initiated, within evidentiary actions, the court may retain an expert witness to provide expert opinion "when it is necessary to have opininon evidence to assist in determining or evaluating an important fact." An expert witness provides expert opinion on a particular matter based on his or her unique experience, education or training." When testifying, expert witnesses "has to take a neutral position, because his or her role is to influence the court through facts rather than emotions." A skilled forensic accountant who possesses a satisfactory level of knowledge and skills in accounting, auditing, and other areas of finance, may, in accordance with the rules of domestic legislation, register as an expert in financial matters and submit his or her expert report stating findings and opinion on a particular aspect of the case at the court's request, independently or within a specific professional institution (Petković, 2010: 161).

c) Other services - within the scope of their activities, forensic accountants may exceptionally serve as mediators to assist one of the parties to the proceedings. 


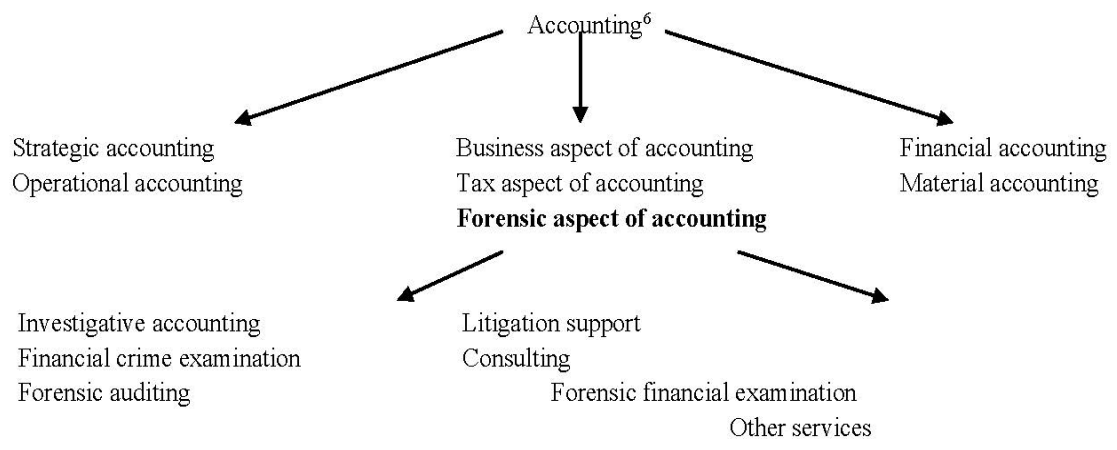

Figure 1: Schematic representation of the place of forensic accounting within accounting activity and its scope (Čudan, Nikoloska, 2018: 261)

The tasks of forensic accountants are to analyze, interpret, summarize, and present interrelated business-financial positions which are understandable and appropriately corraborated. Forensic accountants:

- compile documentation, investigate and analyze evidence of fraud;

- develope computer applications to manage the information collected or present financial evidence;

- communicate their findings in the form of reports;

- provide assistance in litigation, testify in court as expert witnesses, and prepare visual aids to support trial evidence (Dimitrijevic \& Danilovic, 2017: 311).

It may be said that forensic accounting serves to uncover the truth in disputes, therefore forensic experts often appear as witnesses, professional witnesses, expert witnesses, analysts and the like. Forensic accounting is gaining in importance with the rise in the number of frauds, economic crime, and fraudulent misrepresentation.

\section{LEGAL AND INSTITUTIONAL FRAMEWORK FOR FORENSIC ACCOUNTING AND FORENSIC ECONOMIC AND FINANCIAL EXAMINATION}

Forensic accounting is an interdisciplinary field and a forensic accountant should, in addition to his or her knowledge of accounting and its regulation, also be familiar with the legal regulations of the country in which he performs his activities. Forensic accountants, that is, expert witnesses with expertise in economics and finance, are expected to be familiar with domestic criminal, civil, commercial and labor laws. The provision of expert opinion is mentioned by virtually all laws. Expert opinion is required not only because the authority conducting proceedings lack specialized expertise, which is often a court, but also because they cannot independently evaluate those facts that re-

5 Translator's note: Translation of Figure 1. 
quire a certain level of education, training or a qualification even when having relevant expertise (Čudan, 2014).

Material and formal conditions must exist in legal proceedings in order fo forensic examination to be carried out, depending on the expert witness' expertise and skills, that is, the forensic accountant carrying out forensic examination. Material conditions mean that expert witnesses must obtain all relevant data from institutions, organizations or litigant and be qualified to carry out this type of work. Formal conditions mean that expert witnesses must have a written request issued by the authority conducting proceedings to conduct forensic examination.

Procedural law defines the material and formal conditions for conducting forensic examination and the examination process itself, depending on the type of examination, is carried out in accordance with the rules of a specific profession and skills. The material condition requesting forensic examination arises from the need to obtain a finding or opinion from an individual or institution possessing the necessary expert knowledge to evaluate or determine an important fact, while the formal condition requires that the authority conducting proceedings issue a written order requesting forensic examination.

According to the provisions of the Law on Expert Witnesses, ${ }^{6}$ the provision of expert opinion means professional activities performed using scientific, technical and other advances to provide the court or other authority conducting proceedings with the necessary expert knowledge used to establish, evaluate or clarify legally relevant facts. Expert opinion may be provided by natural and legal persons who meet the requirements stipulated by this Law, government institutions, along with scientific and professional institutions.

Article 113 of the Criminal Procedure Code of the Republic of Serbia ${ }^{7}$ stipulates that forensic examination is required in those cases where it is necessary to obtain expert opinion from a person with necessary expertise to evaluate or determine an important fact. The legislature has divided forensic examinations in criminal cases into those explicitly normalized by law and those regulated by general provisions on forensic examination. According to the type of forensic examination, that is, the type of facts to be determined, forensic examination may be divided into:

- forensic examination of a cadaver (forensic pathology);

- forensic examination of personal injuries;

- forensic psychiatric examination;

- forensic examination of the general ledger;

- forensic examination of photographs, audo and video recordings.

Forensic economic and financial examination is at the same time very complex and delicate for the judge who, from a critical point of view, must analyze and evaluate the findings and opinions on matters that do not fall within the experience and knowledge of the judge, because the presentation of evidence can refer to specialized knowledge and scientific disciplines, requiring expertise not available to the court, such as the field of economics and accounting. This type of forensic expertise may be provided by legal and natural persons. Legal entities which may serve as ex-

\footnotetext{
6 Law on Expert Witnesses, Official Gazette of the Republic of Serbia, No. 44 dated 30.06.2010.

7 Criminal Procedure Code, Official Gazette of the Republic of Serbia, No. 35/2019 dated 01.12.2019.
} 
pert witnesses include institutions which can provide forensic services within circumscribed areas, such as Zavod za veštačenje (Bureau of Forensic Science) in Belgrade. Government agencies may also provide forensic services within circumscribed areas. Other organizations such as faculties, institutes, the associations of accountants and auditors play an important role in the provision of forensic services.

Only Serbian nationals can conduct forensic economic and financial examination within our government-owned bodies, while persons who have been registered at the Register of Expert Witnesses may provide expert opinion in legal proceedings. Of course, expert witnesses need to have business acumen, but they also must meet other requirements that make them worthy of the job.

In Serbian judicial practice, there is a formulation which determines who is competent to provide expert opinion in the economic and financial area. Since the term "economic and financial area" is very broad, there are more than ten specialist courses in economic studies today. Therefore, this term must be strictly defined in order to avoid mistakes and omissions encountered in many controversial situations in practice. Due to the fact that someone has been declared competent in the area of economics and finance, it often happens in practice that expert witnesses easily accept an assignment where they do not have the knowledge, experience, qualifications and professional training appropriate for the assignment (Đorđević, 2011).

An expert witness has knowledge, experience, training or skill to determine or evaluate an essential fact in litigation. In order to conduct forensic examination, individuals and legal entities have to meet specific requirements which are prescribed by the provisions of the Law on Expert Witnesses. ${ }^{8}$

The most important court's activity regarding forensic economic and financial examination is the evaluation of expert reports and opinions, that is, testimony. The essence of this evaluation is to determine, in a certain case, whether the opinion formulated by the expert witness has confirmed or denied the existence of a fact in question. In criminal cases, each piece of evidence is evaluated individually and in relation to other evidence, but the evaluation of the opinions provided by financial expert witnesses and is somewhat more complex $^{9}$

8 Official Gazette of the Republic of Serbia, No.44 dated 30.06.2010

9 In practice, it happens that the parties, most often the defendant and his defense counsel, independently obtain expert opinion, which, as a rule, contradicts expert opinion provided by an expert witness appointed by the authority conducting proceedings. Such expert opinion is not procedurally valid, which is why first-instance courts treat it only as a specific form of challenging the findings of the primary forensic examination. 
Table 1. Average duration of trial and forensic examination (in days) for the period 2015-2018. ${ }^{10}$

\begin{tabular}{|l|c|c|c|}
\hline \multicolumn{1}{|c|}{ Duration } & Basic Courts & Commercial Courts & Serbia (average) \\
\hline Average duration of trial & 865 & 519 & 726 \\
\hline $\begin{array}{l}\text { Average duration of forensic } \\
\text { examination }\end{array}$ & 65 & 49 & 54 \\
\hline
\end{tabular}

Source: World Bank, 2018

Comparing the duration of forensic work with the total trial time, the work of expert witness amounted to an average of $7.5 \%$ of the total trial time.

Table 2. Duration of forensic examinaion as \% of trial duration

\begin{tabular}{|c|c|c|c|}
\hline \multicolumn{1}{|c|}{ Duration in \% } & Basic Courts & $\begin{array}{c}\text { Commercial } \\
\text { Courts }\end{array}$ & Serbia (average) \\
\hline $\begin{array}{l}\text { Duration of forensic examination } \\
\text { as \% of trial duration }\end{array}$ & $7,5 \%$ & $8,3 \%$ & $7,5 \%$ \\
\hline
\end{tabular}

Source: World Bank, 2018

With the development of economics, finance and bookkeeping, numerous possibilities of applying research results to determining a questionable factual situation in criminal proceedings are created, such as misdemeanors in the field of economic crime, inappropriate criteria for assessing the qualifications of expert witnesses, inappropriate way of collecting material, gaps in the practical management of expert witness work, uncritical examination of expert witness opinions, and so on.

\section{THE IMPORTANCE AND ROLE OF FORENSIC ECONOMIC AND FINANCIAL EXAMINATION AS A BRANCH OF FORENSIC ACCOUNTING}

It is very difficult to say how important forensic economic and financial examination is, given that opinions concerning the issue are quite different (Coenen, 2008: 124). Some scholars think that forensic examination is just one of many evidentiary means which is not the most important, while others

46 beleive that expert witnesses provide direct assistance to the judge or the authority conducting the fact-finding proceedings or that expert opinions directly influence the decision itself. The importance of expert witnesses and forensic economic examination depends, to a large extent, not only on the quality of

${ }_{10}$ According to statistical data, the duration of forensic examination is not a reason to delay or adjurne hearings. Over the last three years, an average duration of expert witness work amounted to 54 days, 64 days in basic courts and 43 days in commercial courts. 
their reports, but also on the position of the judge conducting proceedings and his or her assessment of the importance of expert reports (Ilić, 2010: 313).

Forensic accountants can support the process through various types of expertise in terms of business assessments, divorce cases, marital disputes, property claims, business partner checks, the evidence of commercial fraud, personal injury and serious accident claims, assessee insurance jobs, warrants to seize property, civil and criminal proceedings concerning fraud and financial irregularities and the like. Therefore, in addition to substantive regulations, the rules governing the procedure before the judicial and other government authorities in civil and criminal proceedings are of particular importance for forensic accountants.

Forensic accountant expert witnesses are independent and they can draw conclusion from and interpret the facts, so that the hired lawyer is right and the opposite party has reached wrong conclusions. If a forensic accountant expert witness proves that he or she is right, then he is a very strong expert witness. Lawyers must assist a forensic accountant expert witness to reach his or her own conclusion so that the lawyer, judge and the jury can understand it. Forensic accountants are not equal regarding their experience and the number of years they have spent in this profession. Some may be IT expert witnesses, some are limited in business, some may be experts in the tax system, some may be experts in auditing, and so on. Also, forensic accountants may be found in the entertainment, clothing, furniture, banking and other industries (Telpner \& Mostek, (2002: 2).

As has already been noted, forensic accountants may serve as expert witnesses as well. When the prosecution calls upon accountants and auditors, they generally testify on the findings obtained during the investigation, and when called upon by the defense, they provide facts about the quality of the findings or opinions presented by an expert for the prosecution so that the jury members may examine the credibility and gravity of the testimony given by an expert witness for the prosecution. Accountants and auditors need to have credibility and be educated in their fields, have sufficient knowledge and skills, be recognized members of their profession, or specialize in a particular aspect of practice relevant to the subject matter. Baring this in mind, there are several areas where expert witnesses are expected to have education and qualifications that differentiate them from laymen (Mikerević et al., 2013: 113).

- Professional license, certificate, and membership of the professional body,

- Undergraduate, graduate and postgraduate degrees - expertise in a spesific field of study or area of professional practice,

- Specialist training and continuing professional education that goes behind academic titles,

- Relevant teaching, lectures and consulting indicating a high level of professionalism in the field,

- Membership in professional associations,

- Direct, relevant experience gained through previous engagements as a technical advisor or expert witness in a given field, 
- Access to information specific to a given case, which classifies an individual as an expert.

The guidelines that need to be followed by expert witness in the preparation and presentation of evidence at trial are the following: expert witnesses need to prepare and study the necessary material in detail, plan their testimony in advance, listen carefully and be alert, carefully consider each answer and take a break before giving answers, be honest and unbiased, use simple words and maintain professional integrity. When an auditor is on the witness stand, the protocol for successful testimony goes beyond merely telling the truth or having good forensic evidence. Auditors must persuade the judge or jurors, leaving them with a great impression (Mikerević et al., 2013: 314).

The task of an expert witness is to assist the court to determine the truth, that is, to establish a certain concreteness of facts with his or her expert witness report or opinion within his or her area of expertise (economics, finance, mechanical engineering, medicine, construction and other areas of human activities) after which a discussion opens or concludes. The course and outcome of litigation or extra-judicial proceedings depend on the quality of expert witness reports and how comprehensive they are.

According to the Law on Expert Witnesses, an expert witness is an expert, that is, a person who is trained to perform a particular activity. In terms of the Law on Expert Witnesses, the Criminal Procedure Code, and the Civil Procedure Code, expert witnesses should have prescribed authorization in the area of professional activity.

In criminal and civil proceedings, expert opinion evidence shall be presented in order to determine or clarify a fact when the court requires the expertise which does not fall within the knowledge of the judge or jury in accordance with the law. In the Serbian literary language, the word veštak means an experienced, skilled, reliable, or seasoned person, but it also means a good connoisseur of something - a connoisseur or expert (Milosevic, 2004).

Lawyers, judges and forensic accountants often view expert witnesses and witnesses differently. Lawyers want expert witnesses to make a decision in favour of their clients, while judges generally want expert witnesses to make a decision when a judge is unable to reach a decision without the assistance of an expert witness. There are situations when more than one opinion is made by forensics available to an expert witness, but the judge wants the facts from the expert witness and his logic without reaching conclusions. This allows the judge to reach his or her own conclusion. A forensic accountant is a person who has an educational background in accounting and is able to assist lawyers at trial to understand and apply accounting law and discuss it. A forensic accounting expert witness has extensive experience in accounting and auditing investigations; he or she can write investigative reports and testify in court as an expert witness. They can be individually hired as litigation consultants. The expert

48 witness must reach his or her own conclusions in court and the client who hired him may also come to the same conclusion as the expert witness (Telpner \& Mostek, 2002: 1).

Expert witnesses focus solely on the forensics of the fraud that has already arisen, based on the case file and material received from the court. They possess the skills to give expert testimony, they examine evidence rather than 
obtain it. Expert witnesses do not affect fraud prevention and fraud detection as forensic accountants do, nor do they evaluate the financial assets and the status of business partners, and many other forensic tasks dealt with by forensic accountants. If forensic accountants want to become expert witnesses, they must go through the legal appointment procedure to become a permanent expert witness.

Forensic accountants do not have to be expert witnesses. Considering the scope of their work, knowledge and skills they possess, forensic accountants may be police inspectors, tax inspectors, market inspectors, commercial forensic experts to evaluate business partners, internal forensic experts, and so on. If one wishes to become a permanent expert witness, the certified forensic accountant credential is different from the decision on being appointed permanent witness expert. In any case, if one wants to become a permanent expert witness, the certified forensic accountant credential will certainly mean proof of his or her knowledge of forensic accounting and thereby contribute to the affirmative decision issued by the court president. In the Republic of Serbia, forensic accounting is still undeveloped. However, some universities offer a forensic accounting course. ${ }^{11}$

Thus, it follows from the aforementioned that the role of forensic accountants in the evaluation or examination process is to use knowledge and skills in litigation. Whether they are hired to detect criminal activity, or as expert witnesses, expert assistant to a prosecutor, witnesses and consultants in litigation, forensic accountants use the same knowledge and skills in accounting, auditing, statistics, economics, and so on.

\section{CONCLUSION}

It may be concluded that the introduction of financial forensic scientist profession in the Republic of Serbia will create well-educated professionals who will use international knowledge and experience in this field and apply them under our conditions. Forensic financial examination in criminal cases is conducted when it is necessary to ascertain facts from the domain of economics, finance and accounting on the basis of business documents and accounting documents. It is the forensic scientists who have the necessary tools and knowledge with effects deadlie than those given through international auditing standards to meet these expectations. Forensic accountants may, based on their expertise, knowledge and experience, be engaged as expert witnesses. When engaged as an expert witness, a forensic accountant can submit his or her report and opinion on specific court cases.

The role of forensic accounting is not to correct social anomalies, but to investigate, in this case, all forms of economic destruction and identify responsible persons. This does not mean that there is no social role for forensic accounting. Forensic work produces a concrete result, and this prevents new perpetrators. An exponent of forensic accounting is a forensic accountant, who can be defined as a person with some expert business-economic and economic-legal knowledge, with characteristics such as competence, education, reli-

\footnotetext{
${ }_{11}$ The course in Financial Forensics offered by the University of Criminal Investigation and Police Studies is taught based on the study program accredited at the graduate levels.
} 
ability, cooperativeness, truthfulness and other virtues. The role of the expert witness in criminal proceedings is irreplaceable and makes a significant and sometimes crucial contribution to the truth.

This paper seeks to draw the attention of the professional public to the need to use forensic economic and financial examination as a form of forensic accounting, which is an indispensable evidentiary means and mechanism in the process of obtaining evidence in criminal and civil cases.

\section{REFERENCES}

Алексић, М., Вујновић-Глигорић, Б., и Уремовић, Н. (2015). Улога и значај форензичког рачуноводства у откривању финансијских превара. Часопис за економију и тржишне комуникације, 5(2), 229-236.

Association of Certified Fraud Examiners. Retrieved from: http://www.acfe.com.

Ђорђевић, Д., Вукасовић, Б. (2011). Економско-финансијско вештачење у судским споровима - Теорија и пракса. Економика , 57(1), 80-96.

Coenen, T., (2008). Essentials of Corporate Fraud. New York: John Wiley \& Sons.

Цветковић, Д., Ђурић, О. (2017). Истражно рачуноводство-инструментоткривања криминалних радњи. Зборник радова Међународног научног скупа ИОРЕДА 2017., (стр. 695-709). Приштина: Економски факултет Универзитета у Приштини са привременим седиштем у Косовској Митровици.

Димитријевић, Д. и Даниловић, М., (2017). Откривање превара у компанијама у Републици Србији применом Бенеисх-овог модела. Анали Економског факултета у Суботици, 37, стр. 311-325.

Чудан А., (2014). Економско финансијско вештачење кроз призму новог закона о судским вештацима као изазов и услов процесу интеграција. Међународна научна конференција: Европска унија и Западни Балкан, (345-357). Београд: Институт за међународну политику и привреду.

Чудан А., Николоска С. (2018). Економски криминал. Београд: Криминалистичко-полицијска академија.

Ивановић А. Б., Ивановић А. Р. (2013). Правци развоја форензике у државама Европе. Правне теме, 2(1), стр. 170-184.

Илић Ј., (2010). Утврђивање одлучних чињеница у управном поступку и у управном спору - вештачењу. Београд.

Микеревић Д., Кондић, Н., Шкарић Јовановић, К., Крсмановић, Б., Шњегота, Д., Пољашевић, Ј., Радивојац, Г., Џакула, М., Пуцаревић, М., Шкобић, 3., Радоњић, С., Видовић, 3., Пајић, П., Панић, Н., Ракић, Д., Тешановић, С. (2013). Форензика пословања. Бања Лука: ФИНРАР.

Милошевић М. (2004). Стање, могућности и перспективе вештачења у области информационих технологија. Научно стручно саветовање, ZITEH, стр. 1-12. преузето са: http://www.itvestak.org.rs/ziteh 04/radovi/ziteh-16.pdf

Петковић, А. (2010). Форензичка ревизија. Бечеј: Пролетер. 
Tjark Tjin-A-Tsoi (2013). Trends, Challenges and Strategy in the Forensic Science Sector. The Netherlands Forensic Institute, Ministry of Security and Justice. преузето са: file:///C:/Users/Korisnik/Downloads/trends-challenges-andstrategy-in-the-forensic-science-sector-march-2013-_tcm120-494231.pdf

Telpner Z., Mostek M., (2002). Expert witnessing in forensic accounting. A handbook for lawyers and accountants. Boca Raton, FL: CRC Press, Taylor \& Francis Group.

Thomas Buckhoff (2008). Forensic Audit vs. Financial Statement Audits, Currents Accounts. Retrieved from :http://www.iagforensics.com/wp-content/ uploads/2009/12/GSCPA-Thomas Buckhoff-ct08.pdf

Закон о кривичном поступку - ЗКП, Службени гласник Републике Србије, бр. 35/19.

Закон о судским вештацима - ЗСВ, Службени гласник Републике Србије, бр.44/10.

Paper received on: 08. 10. 2019.

Paper acceptted for publishing on: 22. 11. 2019. 


\section{ФОРЕНЗИЧКО РАЧУНОВОДСТВО У ФУНКЦИЈИ ЕКОНОМСКО ФИНАНСИЈСКОГ ВЕШТАЧЕЊА ${ }^{1}$}

Прегледни научни рад

\begin{tabular}{|l|l|r} 
DOI 10.5937/zurbezkrim1902041C & COBISS.RS-ID 8629016 & УДК 343.983:657.632
\end{tabular}

Александар Чудан ${ }^{2}$

Криминалистичко-полицијски универзитет, Београд

Драган Цветковић

Полицијска управа за град Београд, Управа криминалистичке полиције

Апстракт: У процесу утврђивања чињеница везано за судске предмете, учествују и вештаци економско-финансијске струке. Потреба за вештачењем у судском поступку, јавља се у ситуацијама у којима суд не поседује потребна стручна знања неопходна за утврђивање свих релевантних чињеница и доношење коначне одлуке, због чега укључује вештака да применом стручних знања и вештина са којима располаже, утврди потребне чињенице. Предмет овог рада је форензичко рачуноводство са посебним акцентом на његов значај и улогу у финансијском вештачењу.

Циљ рада јесте да укаже на важност форензичког рачуноводства, у функцији економско - финансијског вештачења као и да се укаже на неопходност његовог даљег усавршавања и развоја. Практични циљ научног рада усмерен је на покушај аутора да финансијску форензику промовише као професију новог миленијума. С обзиром на турбулентну прошлост и очекивану будућност Република Србија несумњиво има потребе за овом врстом кадрова.

Кључне речи: форензичко рачуноводство, вештак, судски поступак, превара, форензика.

\section{УВОД}

Форензика као примена знања и технологија из широког спектра наука, пружа одговоре валидне за суд, било да се ради о кривичном или парничном поступку, подразумевајући истовремено примену науке у спровођењу закона. У развијеним земљама, односно у државама Европске уније, у протеклој деценији, број истрага форензичких испитивања повећао се неколико пута, а за пример може се навести Холандски форензички институт (The Netherlands Forensic Institute) као један од најразвијених у Европи, где се

\footnotetext{
1 Рад је резултат истраживања на пројекту: „Криминалитет у Србији и инструменти државне реакције“, који финансира и реализује Криминалистичко полицијска академија у Београду, циклус научних истраживања 2015-2019.година

2 Аутор за кореспонденцију: др Александар Чудан, ванредни професор на Криминалистичкополицијском универзитету у Београду. E-mail: aleksandar.cudan@kpu.edu.rs
} 
од почетка новог миленијума, број запослених увећао чак три пута (Tjark, 2013:3).

Форензичка наука у последње време развила се у многим смеровима па тако и у смеру форензичког рачуноводства. То је узроковало велике штете у привреди које настају због превара и лажних финансијских извештаја (Чудан, 2014). Форензичко рачуноводство, као посебна грана рачуноводства бави се коришћењем рачуноводствене експертизе у циљу спречавања и испитивања различитих видова криминалних радњи унутар привредног друштва, али и прикупљања доказа који ће бити валидни за судски поступак. Многобројни примери финансијских скандала у протеклој периоду, указали су на недостатке и ограничења ревизије у поступку откривања криминалних радњи, а самим тим и неопходности примене форензичког рачуноводства и уношења његове експертизе у процес испитивања и откривања различитих видова криминалних радњи.

Докази форензичке анализе се прикупљају на начин да буду прихватљиви за суд који процесуира извршиоце. Како ће суд реаговати није у домену форензичког рачуноводства. Због тога форензичари и њихова специјалистичка знања постају карика која употпуњује и чини још ефикаснију борбу против економског криминалитета.

У савременим условима, готово не може се замислити окончање нити једног кривичног поступка из области економских деликата у којем се као извор доказа није појавио вештак форензичар, односно лице које располаже стручним знањем и вештинама које су потребне за утврђивање или оцену неке важне чињенице. Постизање поштовања стручних правила и спровођење њихове стварне употребе је могуће користећи иновативне гране књиговодствено-рачуноводствене делатности: форензичког рачуноводства. С обзиром на то, да форензички рачуновођа, осим ревизије, рачуноводства и финансијског извештавања познају и друге области, укључујући познавање правних прописа и закона, актуарства, статистике, софтверских алатки, али и психологије личности, добијају на значају не само у отркивању превара већ и у области вештачења економско-финансијске природе, било у кривичном или парничном, поступку у циљу прикупљању доказа који ће бити валидни за судски поступак, а самим тим и разрешењу случаја. Уважавајући претходно изнето чињеница је да је економско-финансијско вештачење, нашло есенцијално место у широком спектру форензичких наука.

У раду је дефинисан појам форензичког рачуноводства, представљени су делокруг и задаци форензичког рачуноводства, правни и институционални оквир форензичког рачуноводства и финансијског вештачења, као и значај и улога економско - финансијског вештачења у судским поступцима.

\section{ФОРЕНЗИЧКО РАЧУНОВОДСТВО: ПОЈАМ, ДЕЛОКРУГ И}

\section{ЗАДАЦИ}

У савременом коришћењу, термин форензика се често користи уместо термина форензичка наука. С обзиром да термин форензички представља синоним за йравни или који се оgноси на суg ова замена термина се не може сматрати довољно прецизном. Ипак, термин се у толикој мери усталио у 
савременом језику да многи речници садрже значење које изједначава речи форензика и форензичка наука.

Форензика у најширем смислу подразумева примену знања и технологија из различитих форензичких наука у решавању правних питања. Форензика у практичној примени експлоатише сопствене искуствене методе, као и методе осталих наука и дисциплина које у пракси прилагођава сопственим потребама, при чему оне, прилагођене и осавремењене, нужно добијају практични инструктиван значај. Управо услед коришћења различитих форензичких анализа, ова врста доказа не ретко има пресудну улогу хоће ли пријављени, односно оптужени бити проглашен кривим или не. Дакле, форензика подразумева примену научних метода код откривања и тумачења (вештачења) материјалних трагова, због чега се и стручњаци који обављају ове послове називају форензичари (Ивановић и Ивановић, 2013).

Од мноштва дефиниција које егзистирају у стручној литератури која се бави форензичким рачуноводством најприхватљивијом и најпотпунијом се сматра она коју је озваничило Удружење овлашћених истражитеља превара (ACFE) $)^{3}$ по којој форензичко рачуноводство представља коришћење рачуноводствених вештина у потенцијалним или стварним цивилним или кривичним споровима, укључујући општеприхваћене рачуноводствене и ревизорске принципе, у циљу утврђивања изгубљених профита, прихода, имовине или штете, процене ефикасности интерних контрола, откривања превара или реализације других активности које захтевају укључивање рачуноводствених експертиза у правни систем (Цветковић и Ђурић, 2017).

И поред обављања широког спектра послова, форензичко рачуноводство може се одвијати на два примарна подручја:

1. Исииражно рачуновоgсииво, пресвега има за циљ детектовање и разоткривање преваре када постоји сумња да је учињена деструктивна инкриминисана радња у финансијским извештајима, односно када се пословање клијента превентивно проверава. Истражно рачуноводство подразумева свеобухватно истраживање криминалних радњи. Такође поменута дисциплина уважава и интегрише знања из рачуноводства, ревизије и истражних техника а може се јавити у два облика:

а) Финансијско-криминалистичка испитивања - ово је посебна дисциплина форензичког рачуноводства која истражује преваре у финансијским извештајима. Ова врста испитивања подразумева проактивни и реактивни приступ методологији усмерен на уочавање и препознавање превара у финансијским извештајима. Овај вид форензичког рачуноводства карактеристичан је за истражитељи који обично потичу из државних контролних и истражних/детективских агенција, ревизорских кућа и криминалистичких служби.

\footnotetext{
3 Association of Certified Fraud Examiners (ACFE) је независна, научна и професионална мултидисциплинарна организација која покрива велики број форензичких дисциплина или сличних области укључујући и форензичко рачуноводство. Сврха ACFE је да својим члановима обезбеди континуирано усавршавање из области форензичког рачуноводства и саветовања на многим професионалним пољима. ACFE је кроз едукацију и обуку подигао стандарде на виши ниво. Један од сертификата који издаје ACFE је Овлашћени форензички рачуновођа (Cr. FA). ACFE је и лидер у стручној обуци и тренингу за борбу против превара, чиме стиче велики углед и поверење јавности у струку као инструмент борбе против превара. Основни циљ ове организације јесте да смањи учесталост превара и помогне свом чланству у откривању превара
} 
Ради се о тиму страчњака са различитим знањима, вештинама и искуствима које користе у откривању и документовању криминалних радњи.

b) Форензичка ревизија финансијских извештаја је нова специјализована услуга у оквиру процеса ревизије финансијских извештаја. Форензичка ревизија подразумева уговарање посебног ангажовања са ревизорским кућама и захтева рад ревизора са посебном обуком и искуством у спречавању и откривању превара. ${ }^{4}$

2) Судска подршка, која има за циљ пружање професионалних услуга када су одређене радње већ идентификоване и ушле у судски процес. Односи се на пружање професионалних услуга лицима која су укључена у судске поступке. Професионалне услуге врше лица која поседују рачуноводствене и ревизорске вештине и друга знања која доприносе решавању спорова, попут економско - финансијског вештачења, консултантских и других услуга (Алексић, Вујновић-Глигорић, и Уремовић, 2015). Амерички институт овлашћених јавних рачуновођа (АІСРА) дефинише услуге судске подршке као било коју професионалну подршку која се пружа адвокатима у судским процесима од стране особа које по професији нису адвокати . Услуге судске подршке могу се класификовати у три области и то:

а) Консултантске услуге - путем ових услуга форензичке рачуновође пружају савете у вези са рачуноводствено-финансијским питањима која су важна за судски поступак. Консултант се не појављује, нити сведочи као судски вештак у поступку већ, користећи своја рачуноводствена и ревизорска знања и вештине, на разне начине помаже адвокатима и/или једној од страна у поступку пред судом. Форензички рачуновођа може мерити економске штете, или губитке услед рецимо кршења или раскида уговора, затим управљати, сортирати, индексирати и сажимати велики број рачуноводствених података, како би исти били разумљиви и употребљиви у судском предмету.

b) Услуге економско - финансијског вештачења - форензичке рачуновође се могу, на основу њихових искуства, знања и експертиза, ангажовати на суду у улози судског вештака. У својству ангажованог судског вештака форензички рачуновођа може доставити свој извештај и мишљење у вези поверених судских предмета. У већ отпочетим судским поступцима, у оквиру радњи доказивања, суд може затражити и спровођење радњи вештачења „када је за утврђивање или оцену неке важне чињенице потребно прибавити налаз и мишљење од лица које располаже потребним стручним знањем.“ Вештачење обавља судски вештак, у суштини „сведок суда који може пружити мишљења у вези одређеног питања, заснованог на јединственом искуству, образовању или обуци." Судски вештак „мора сведочити са позиције неутралности, јер његова улога није да на суд утиче путем емоција већ чињеница." Искусан форензички рачуновођа, који располаже задовољавајућим степеном знања и вештина из рачуноводства, ревизије и других области

\footnotetext{
4 Forensic Audit vs. Financial Statement Audits, Currents Accounts, (2008), преузето са сајта:http:// www.iagforensics.com/wp-content/uploads/2009/12/GSCPA-Thomas Buckhoff-ct08.pdf
} 
финансија, може се у складу са прописима домицилног законодавства регистровати као судски вештак финансијске струке, и као такав самостално или у оквиру одређене стручне установе на захтев суда, по одрећеном судском предмету доставити свој налаз и мишљење (Петковић, 2010:161).

c) Остале услуге - у опсегу свог деловања форензичке рачуновође се изузетно могу у оквиру судских процеса јавити у посебној улози медијатора неке од страна у самом судском поступку, од суда именован експерт за сведочење и слично.

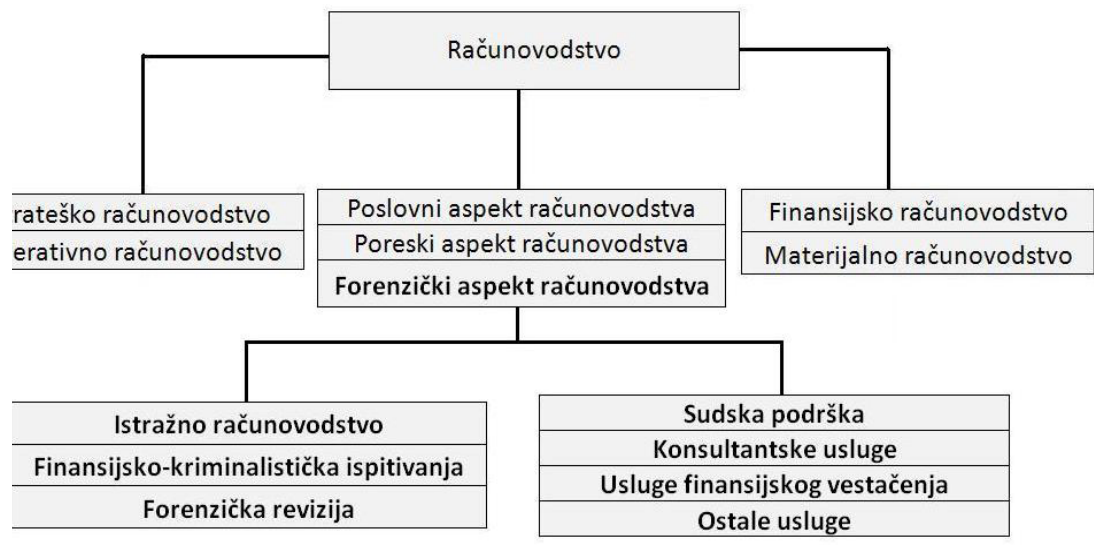

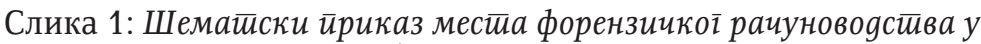

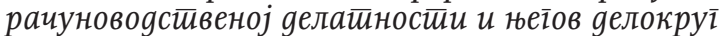

(Чудан, Николоска, 2018: 261)

Задаци форензичких рачуновођа јесу да анализирају, интерпретирају, сумирају и презентирају међусобно повезане пословно-финансијске позиције, тако да буду разумљиве и на одговарајући начин поткрепљене. Форензичке рачуновође учествују у следећим активностима:

- истраживању и анализирању доказа о учињеној превари;

- развијању компјутеризованих апликација које ће послужити у анализама и презентацијама о финансијским доказима;

- презентацијама резултата истраживања у виду извештаја и комплетирања документације;

- асистирању у правним поступцима, укључујући сведочења на суду у улози сведока-стручњака, те припремању визуелних средстава која ће служити као доказ на суђењу (Димитријевић, Даниловић, 2017: 311).

Може се рећи, да ова професија служи откривању истине у споровима, па се форензичари често јављају у улози сведока, експерата, вештака, аналитичара и слично. Форензичко рачуноводство све више добија на зна- 
чају са порастом броја превара, привредног криминала као и лажног приказивања стања имовине и успеха привредних субјеката.

\section{ПРАВНИ И ИНСТИТУЦИОНАЛНИ ОКВИР ФОРЕНЗИЧКОГ РАЧУНОВОДСТВА И ЕКОНОМСКО - ФИНАНСИЈСКОГ ВЕШТАЧЕЊА}

Како је форензичко рачуноводство интердисциплинарно подручје, форензички рачуновођа поред познавања рачуноводства и његове регулативе треба да буде упознат и са правним прописима државе у којој реализује своје активности. За рад форензичких рачуновођа, односно судских вештака у економско-финансијској области, посебно је значајно, поред осталих грана, познавање кривичног, грађанског, привредног и радног права домицилне државе. Вештачење се спомиње у практично свим законима. Разлог за одређивање вештачења није само у недостатку специјализованих стручних знања органа који воде поступак већ и у томе што сам орган поступка најчешће суд ни онда када располаже одговарајућим стручним знањем не може самостално ценити оне чињенице за чије је утврђивање и оцењивање потребна одређена стручна спрема, оспособљеност или квалификација (Чудан, 2014).

Како би се спровео поступак вештачења, у судском процесу, морају постојати материјални и формални услови у зависности од експертизе, струке и вештина вештака, односно форензичког рачуновође који врши ову улогу. Материјални услови се односе на то да вештаци морају прикупити све релевантне податке од установа, организација, институција или лица која се налазе у судском спору и морају бити квалификовани за обављање ове врсте посла. Формални услови се односе на то да вештаци морају имати писмену наредбу од од органа који воде судски спор.

Процесним законом одређени су материјални и формални услови за спровођење вештачења, а сам поступак вештачења, зависно од врсте експертизе спроводи се по правилима конкретне струке и вештине. Материјални услов за одређивање вештачења произилази из потребе да је за оцену, односно утврђивање неке важне чињенице потребно прибавити налаз или мишљење од лица или установе који располажу потребним стручним знањем, а формални услов да спровођење вештачења писменом наредбом одреди орган који води поступак.

Према одредбама Закона о судским вештацима ${ }^{5}$ послови вештачења представљају стручне активности чијим се обављањем, уз коришћење научних, техничких и других достигнућа, пружају суду или другом органу који води поступак потребна стручна знања која се користе приликом утврђивања, оцене или разјашњења правно релевантних чињеница. Вештачење

46 обављају физичка и правна лица која испуњавају услове предвићене овим законом, државни органи у оквиру којих се може обавити вештачење, као и научне и стручне установе.

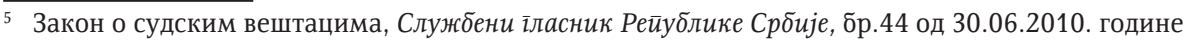


Законик о кривичном поступку Републике Србије ${ }^{6}$ одредбом чланом 113 предвиђа да се вештачење одређује у свим случајевима када за оцену или утврђивање неке важне чињенице неопходон прибавити налаз и мишљење од лица која располаже неопходним стручним знањем. Законодавац је вештачења у кривичном поступку поделио на она која су у закону експлицитно нормирана и сва остала које су регулисана општим одредбама о вештачењу. Према предмету вештачења, односно према врсти чињеница које се утврђују вештачење се дели на:

- вештачење у вези лишења живота;

- вештачење телесних повреда;

- вештачење душевног стања;

- вештачење пословних књига;

- вештачење фотографија и звучних и видео снимака.

Економско-финансијско вештачење је истовремено врло сложено и деликатно за судију који мора са критичког становишта да анализира, оцени налаз и мишљење о материји коју не познаје довољно, јер се иначе извођење доказа вештачењем може односити на различите гране струке и науке, за које је потребно стручно знање којим суд не располаже, у овом случају из области економије и књиговодства. Овом врстом вештачења могу да се баве правна и физичка лица. Правна лица која могу давата налаза и мишљења у својству вештака су пре свега посебне организације које су основане да се баве вештачењем, и којима је то претежна делатност. Таква установа је Завод за вештачење у Београду. Вештачењем могу да се баве и државни органи за вештачење чињенице из области за које су основане. Посебну значајну улогу у процесу вештачења имају и друге организације посебно оне из области науке, факултети, институције и удружења књиговођа и ревизора.

Економско-финансијским вештачењем код наших органа се могу бавити само лица која су држављани Србије, а у поступцима пред судовима само она лица која су уписана у регистар судских вештака. Наравно вештаци морају имати пословну способност али испуњавати и друге услове које их чини достојним за обављање тог посла.

У пракси српског правосуђа постоји формулација по којој се утврђује да је неко компетентан за судска вештачења у економско-финансијској области. Појам „економско-финансијска област“ је у савременом свету веома широк па се на економским студијама данас појављује више од десет специјалности. С тога овај појам мора да буде строго дефинисан како се не би догађале грешке и пропусти које сусрећемо у многим спорним ситуацијама у пракси. Из чињенице да је неко проглашен компетентним за вештачење у економско-финансијској области, у пракси се догађају ситуације да се вештаци олако опредељују да вештаче предмете у области за које нису професионално оспособљени. (Ђорђевић, 2011)

Вештак је лице које располаже посебним експертским знањем и вештинама за утврђивање односно оцену неке есенцијалне чињенице у поступку. Конкретни услови које физичка и правна лица морају да испуњавају

6 Закон о кривичном поступку Службени іласник Рейублике Србије, бр. 35/2019 од 01.12.2019. године. 
за обављање послова вештачења, прописани су одредбама Закона о судским вештацима. ${ }^{7}$

Најважнија активност суда када је у питању економско-финансијско вештачење је оцена налаза и мишљења вештака, односно његовог исказа. Суштина ове оцене јесте да се у сваком конкретном случају утврди да ли је вештачењем потврђено или негирано постојање неке спорне чињенице. У кривичном поступку сваки доказ се цени појединачно и у вези са другим доказима, с тим што је оцена налаза и мишљења финансијског вештака нешто сложеније. ${ }^{8}$

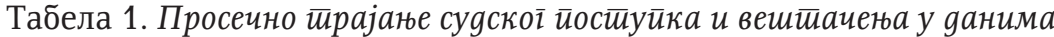
за 2015-2018.íoguнy. ${ }^{9}$

\begin{tabular}{|c|c|c|c|}
\hline \multicolumn{1}{|c|}{ Време трајања } & $\begin{array}{c}\text { Основни } \\
\text { судови }\end{array}$ & $\begin{array}{c}\text { Привредни } \\
\text { судови }\end{array}$ & Р.Србија просек \\
\hline $\begin{array}{l}\text { Просечно трајање судског } \\
\text { поступка }\end{array}$ & 865 & 519 & 726 \\
\hline \hline Просечно трајање вештачења & 65 & 49 & 54 \\
\hline
\end{tabular}

Извор: Светска банка, 2018. година

Уколико се трајање вештачења упореди са укупним трајање судског поступка, уочљиво је да вештачење у просеку траје 7,5\% укупног трајања судског поступка.

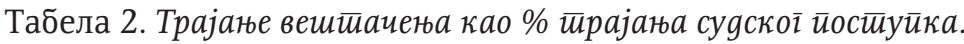

\begin{tabular}{|c|c|c|c|}
\hline Време трајања у \% & $\begin{array}{c}\text { Основни } \\
\text { судови }\end{array}$ & $\begin{array}{c}\text { Привредни } \\
\text { судови }\end{array}$ & Р.Србија просек \\
\hline $\begin{array}{l}\text { Трајање вештачења као \% } \\
\text { трајања судског поступка }\end{array}$ & $7,5 \%$ & $8,3 \%$ & $7,5 \%$ \\
\hline
\end{tabular}

Извор: Светска банка, 2018. година

7 Службени ілласник Рейублике Србије, бр.44 од 30.06.2010. године

8 У пракси се дешава да странке, најчешће окривљен и његов бранилац самостално прибаве налаз и мишљење вештака који је по правилу у супротности са налазом и мишљењем вештака којега је одредио орган поступка. Такав налаз и мишљење нема процесну ваљаност, због чега га судови у првостепеном поступку третирају само као одређени вид приговора и примедби на основни налаз и мишљење.

9 Према статистичким подацима трајање вештачења није разлог за одуговлачење судских поступака. Вештачења су у току протекле три године у просеку трајала по 54 дана и то нешто више, 64 дана пред основним судовима, а 43 дана пред привредним судовима. 
Развојем економије, финансија, књиговодства, шире се могућности примене њихових достигнућа путем вештачења на утврђивање спорног чињеничног стања у кривичном поступку када су у питању деликти из области економског криминалитета, као што су неодговарајући критеријуми за процену стручности вештака, неадекватан начин прикупљања и обезбеђења материјала, пропусти у практичном руковођењу вештачењем, некритички однос према резултатима вештачења и друго.

\section{ЗНАЧАЈ И УЛОГА ЕКОНОМСКО ФИНАНСИЈСКОГ ВЕШТАЧЕЊА КАО ЈЕДНЕ ОД ОБЛАСТИ ФОРЕНЗИЧКОГ РАЧУНОВОДСТВА}

Одговор на дилему колики значај има економско-финансијска вештачења тешко је децидирано дати с обзиром да се о овом питању воде расправе о ставовима који су прилично удаљени (Coenen, 2008: 124). Они се крећу од тога да је вештачење само један од доказних средстава, и то не најважнијих, преко става да вештаци пружају непосредну помоћ судији или органу који води поступак у утврђивању чињеница, до тога да постоји мишљење да се вештачењем директно утиче на само доношење одлуке. У великој мери значај вештака и вештачења из области економских наука зависи од квалитета његовог налаза али и од става судије који води поступак и од његове оцене о значају вештачења (Илић, 2010: 313).

Форензичке рачуновође могу пружати подршку у оквиру поступка кроз различите видове експертизе у смислу пословних процена, бракоразводних парница, брачних спорова, потраживања имовине, провере пословних партнера, доказивања привредних превара, телесних повреда и потраживања код тешких несрећа, послова проценитеља код осигурања, захтевних налога за одузимање имовине, грађанских и казнених поступака у вези преваре и финансијских неправилност и слично. Стога су, поред материјалних прописа, за форензичког рачуновођу од посебне важности и прописи који уређују процес пред судским и другим државним органима - у којима се по важности издвајају парнични и кривични поступци.

Сведок вештак рачуновођа је независтан и он може доносити закључке из чињеница и интерпретирати их, тако да је ангажовани адвокат у праву и да је супротна страна донела погрешне закључке. Ако сведок вештак рачуновођа докаже да је он у праву, онда је он један веома јак сведок вештак. Адвокати морају помоћи вештаку сведоку рачуновођи да донесе свој закључак како би адвокати, судија и порота могли да га разумеју. Форензичке рачуновође нису једнаке, ако гледамо њихово искуство и колико година су провели у овој професији. Неки су можда ИТ вештаци, неки од њих су лимитирани у послу, неки су можда вештаци у пореском систему, неки можда вештаци у ревизији, и тако даље. Постоје и форензичке рачуновође вештаци у индустрији забаве, одеће, намештаја, банака и других индустријА (Telpner \& Mostek, 2002: 2).

Као што је већ напоменуто форензички рачуновођа игра улогу и стручног сведока. Када тужилаштво позове рачуновође и ревизоре, они углавном сведоче о налазима до којих су дошли током истраге, а када их позове одбрана, они износе чињенце о квалитету налаза или мишљења које је изнео рачуноводствени вештак тужилаштву, како би чланови пороте 
испитали кредибилитет и тежину сведочења стручњака тужилаштва. Рачуновође и ревизорају морају имати кредибилитет, морају бити едуковани у својим областима, морају имати довољно знања и вештина, морају бити признати чланови своје професије или бити специјализовани за одређени аспект праксе који је значајан за дати предмет. Имајући ове информације у виду, постоји неколико широких подручја у којима се од сведока вештака очекује да поседује образовање и квалификације које их разликују од обичних лаика, што укључује (Микеревић и сар., 2013:113):

- Професионалну лиценцу, сертификат и чланство код признатог професионалног тела,

- Основни, дипломски и постдипломски степен за одређену област експертизе,

- Специјалистичку обуку и континуирану професионалну едукацију која п ревазилазиоквире академских титула,

- Релевантне наставе, предавања и консталтинг који указује на висок ниво професионалности у датој области,

- Чланство у професионалним удружењима,

- Директно, релевантно, претходно искуство које је стечено кроз претходна ангажовања, у својству техничког саветника или стручног сведока у датој области,

- Приступ информацијама које су карактеристичне за дати случај, што појединца класификује као стручњака.

Смернице за стручног сведока које треба да се упамте и код припреме и код давања доказа на суду се односе на то да сведоци припреме целокупни материјал, да детаљно проуче тај материјал, унапред испланирају своје сведочење, пажљиво слушају и буду на опрезу, пажљиво размотре сваки одговор и направе паузу пре него што дају одговоре, буду искрени и непристрасни, користе једноставне речи и очувају професионално држање и интегритет. Када се ревизор нађе на клупи за сведоке, протокол у вези са успешним сведочењем превазилази само говорење истине или поседовање добрих форензичких доказа. Ревизори морају да убеде судију или поротнике и да при томе оставе добар утисак (Микеревић и сар., 2013:314).

Задатак вештака је да својим експертским налазом или мишљењем из области за коју је стручан (економија, финансије, машинство, медицина, грађевинска и друге области људских активности) помогне суду да се утврди истина, односно да утврди одређену конкретност чињеница након чега се отвара или закључује расправа. Од квалитета и свеобухватности налаза и мишљења судског вештака зависи ток и исход судског или вансудског поступка.

Према Закону о судским вештацима, вештак је експерт, односно особа која је обучена за обављање одређене делатности. У смислу Закона о суд-

50 ским вештацима, Закона о кривичном поступку и Закона о парничном поступку, вештак треба да поседује и прописана овлашћења у области стручног деловања.

У судским поступцима, кривичном и парничном, извешће се доказ вештачењем ради утврђивања или разјашњења неке чињенице кад је потребно стручно знање којим суд не располаже у складу са законима. У српском 
књижевном и народном језику речју вешйак означава се искусан, вешт, поуздан или опробан човек, али истовремено и добар познавалац нечега - зналац тј. стручњак (Милошевић, 2004).

Адвокати, судије и форензичке рачуновође често имају другачији поглед на вештаке и сведоке. Адвокати желе да вештаци донесу одлуку која ће бити позитивна за њихове клијенте. Судије углавном желе да вештаци донесу одлуку када судија није у стању да донесе одлуку без помоћи вештака. Постоји ситуација када се доноси и више од једном мишљења од стране форензике доступне вештаку, али судија жели чињенице од вештака и његову логику без доношења закључака. Ово дозвољава судији да донесе свој закључак. Форензички рађуновођа је онај који има знања из рачуноводства и који је способан да асистира адвокатима у суду да разумеју и примењују рачуноводство у праву и да расправљају о томе. Вештак форензичког рачуноводства има велико искуство у истрагама које су везане за рачуноводство и ревизији, могу да пишу извешаје о истрази, и да се појаве на суду као вештаци сведоци. Они се могу појединачно ангажовати као консултанти на суду. Вештак као сведок треба да донесе сопствени закључак на суду и клијент који га је ангажовао такође може доћи до истог закључка као и сведок вештак (Telpner \& Mostek, 2002:1).

Судски вештак је усмерен искључиво на форензику већ настале преваре и то на темељу предмета и материјала које добије од суда. Он поседује вештине експертног сведочења, али не прибавља доказе него их само вештачи. Судски вештак не делује на превенцији преваре и откривању превара као што то раде форензичари рачуновође нити се бави проценом финансијске имовине или положаја пословних партнера као ни многим другим пословима којима се форензички рачуновођа бави. Ако форензичари рачуновође хоће и желе да буду и судски вештаци онда морају да прођу кроз законски поступак именовања сталним вештаком.

Форензичке рачуновође не морају бити судски вештаци. Узимајући у обзир делокруг, знање и вештине које поседују, форензичке рачуновође могу бити полицијски инспектори, порески инспектори, тржишни инспектори, комерцијални форензичари за процену пословних партнера, интерни форензичари, и тако даље. Ако неко жели да постане стални судски вештак, сертификат за овлашћеног форензичког рачуновођу је одвојен од решења о именовању за сталног судског вештака. У сваком случају, ако неко жели да постане стални судски вештак, сертификат за овлашћеног форензичког рачуновођу ће сигурно значити доказ његовог знања из форензичког рачуноводства и тиме допринети да председник суда који доноси решење донесе потврдну одлику. У Републици Србији форензичко рачуноводство није толико развијено, међутим на одређеним универзитетима се појављује форензичко рачуноводство као предмет. ${ }^{10}$

Дакле, из свега изнетог произилази да је улога форензичког рачуновође у поступку вештачења, коришћење знања и вештине у судском спору. Небитно да ли се ангажују како би открили криминалне радње, или у судском спору у својству вештака, стручног сарадника тужиоца, сведока, кон-

10 Наставни предмет финансијска форензика на Криминалистипко-полицијском универзитету изучава се на основу акредитованог студијског програма на студијама другог степена. 
султанта, форензичке рачуновође користе иста знања и вештине из рачуноводства, ревизије, статистике, економије, и тако даље.

\section{ЗАКЉУЧАК}

Закључујемо да ће увођење професије финансијског форензичара у Републици Србији, створити квалитетно образоване професионалце који ће искористити међународна сазнања и искуства из ове области, те их применити у нашим условима. Финансијско вештачење у кривичним поступцима спроводи се у околностима када је потребно утврдити чињенице из домена економске, финансијске и рачуноводствене струке на бази пословне документације и рачуноводствених исправа. Управо форензичари имају неопходне алате и знања који су убојитијег дејства од оних који су дати у руке путем међународних стандарда ревизије да одговоре на ова очекивања. Форензичке рачуновође се могу, на основу њихових експертиза, знања и искуства, ангажовати на суду у улози судског вештака. Као ангажовани судски вештак форензички рачуновођа може доставити свој извештај и мишљење у вези одређених судских предмета.

Улога форензичког рачуноводства није да исправља друштвене аномалије, већ да истражује, у овом случају све видове економских деструкција и да индентификује одговорна лица. То никако не значи да не постоји и друштвена улога форензичког рачуноводства. Форензички рад доноси конкретан резултат, а то спречава нове починитеље. Експонент активности форензичког рачуноводства је форензички рачуновођа, кога можемо дефинисати као лице са извесним експертским пословноекономским и економско-правним знањима, који има све карактеристике: компетентност, образованост, поузданост, кооперативност, истинољубивост и друге врлине. Улога вештака у кривичном поступку је незаменљива и даје значајан понекад и пресудан допринос у утврђивању истине.

Кључна порука овог рада јесте да се скрене пажња стручној јавности на потребу примене економско-финансијског вештачења као облика форензичког рачуноводства, што представља незаобилазно доказно средство и механизам у поступку прибављања доказа у кривичним и парничним поступцима.

\section{ЛИТЕРАТУРА}

Алексић, М., Вујновић-Глигорић, Б., и Уремовић, Н. (2015). Улога и значај форензичког рачуноводства у откривању финансијских превара. Часопис за економију и тржишне комуникације, 5(2), 229-236.

Association of Certified Fraud Examiners. Преузето: http://www.acfe.com.

Ђорђевић, Д., Вукасовић, Б. (2011). Економско-финансијско вештачење у судским споровима - Теорија и пракса. Економика , 57(1), 80-96.

Coenen, T., (2008). Essentials of Corporate Fraud. New York: John Wiley \& Sons.

Цветковић, Д., Ђурић, О. (2017). Истражно рачуноводство-инструментоткривања криминалних радњи. Зборник радова Међународног научног скупа ИОР- 
ЕДА 2017.. (стр. 695-709). Приштина: Економски факултет Универзитета у Приштини са привременим седиштем у Косовској Митровици.

Димитријевић, Д. и Даниловић, М., (2017). Откривање превара у компанијама у Републици Србији применом Бенеисх-овог модела. Анали Економског факултета у Суботици, 37, стр. 311-325.

Чудан А., (2014). Економско финансијско вештачење кроз призму новог закона о судским вештацима као изазов и услов процесу интеграција. У: Зборнику радова са међународне научне конференције. Европска унија и Западни Балкан. (345-357). Београд: Институт за међународну политику и привреду.

Чудан А., Николоска С. (2018). Економски криминал. Београд: Криминалистичко-полицијска академија.

Ивановић А. Б., Ивановић А. Р. (2013). Правци развоја форензике у државама Европе. Правне теме, 2(1), стр. 170-184.

Илић J., (2010). Утврђивање одлучних чињеница у управном поступку и у управном спору - вештачењу. Београд.

Микеревић Д., Кондић, Н., Шкарић Јовановић, К., Крсмановић, Б., Шњегота, Д., Пољашевић, Ј., Радивојац, Г., Џакула, М., Пуцаревић, М., Шкобић, З., Радоњић, С., Видовић, З., Пајић, П., Панић, Н., Ракић, Д., Тешановић, С. (2013). Форензика пословања. Бања Лука: ФИНРАР.

Милошевић М. (2004). Стање, могућности и перспективе вештачења у области информационих технологија. Научно стручно саветовање, ZITEH, стр. 1-12. преузето са: http://www.itvestak.org.rs/ziteh_04/radovi/ziteh-16.pdf

Петковић, А. (2010). Форензичка ревизија. Бечеј: Пролетер.

Telpner Z., Mostek M., (2002). Expert witnessing in forensic accounting. A handbook for lawyers and accountants. Boca Raton, FL: CRC Press, Taylor \& Francis Group.

Tjark Tjin-A-Tsoi (2013). Trends, Challenges and Strategy in the Forensic Science Sector. The Netherlands Forensic Institute, Ministry of Security and Justice. преузето са: file:///C:/Users/Korisnik/Downloads/trends-challenges-andstrategy-in-the-forensic-science-sector-march-2013-_tcm120-494231.pdf

Thomas Buckhoff (2008). Forensic Audit vs. Financial Statement Audits, Currents Accounts. преузето са : http://www.iagforensics.com/wp-content/ uploads/2009/12/GSCPA-Thomas Buckhoff-ct08.pdf

Закон о кривичном поступку - ЗКП, Службени гласник Републике Србије, бр. 35/19.

Закон о судским вештацима - ЗСВ, Службени гласник Републике Србије, бр.44/10.

Рад примљен: 08. 10. 2019.

Рад прихваћен: 22. 11. 2019. 